\title{
Towards the Information Society - the Case of Finnnish Teacher Education
}

\author{
Juhani RAUTOPURO, Susanna PÖNTINEN, Jari KUKKONEN \\ Department of Applied Education, University of Joensuu \\ P.O. Box 111, 80101 Joensuu, Finland \\ e-mail: \{juhani.rautopuro, susanna.pontinen, jari.kukkonen\}@joensuu.fi
}

Received: May 2006

\begin{abstract}
The use of Information and Communication Technology (ICT) in education is one important competence that student teacher should develop in their academic studies. To be capable of using ICT in education, students should study both pedagogical and technical issues. In order to affect student teachers' willingness to use ICT in education, more attention should be paid to their learning experiences. In this research, student teachers' attitudes toward the use of ICT in education were studied before and after the web-based course. Based on students' learning experiences, attitudes and evaluations of the web-based learning environment, dimensions of a successful webbased learning environment were examined. According to the results, "motivation and accuracy", "learner-interface interaction" and "learner control and self-directed learning"are the dimensions of a learning environment that encourages student teachers' to use ICT in education. A well designed learning environment also gave a realistic overview and knowledge of the possibilities and limitations of the use of ICT in education.
\end{abstract}

Key words: ICT in education, teacher education, dimensions of a good online learning environment.

\section{Introduction}

\subsection{Finnish Pupils in the International ICT-Context}

According to the PISA 2003 (Programme for International Student Assessment) report Finnish 15-year-olds were among the best in all school domains (mathematics, science, reading literacy, and problem solving) which were assessed in the survey comprising of 41 countries. Moreover, the study showed that regular computer users performed better in key school subjects, the quality of the use being more important than the volume of the use of computers.

Further analyses of the PISA data carried out by the Organisation for Economic Cooperation and Development (OECD, 2006) showed that the possibilities of using computers in Finland are very good. About $96 \%$ of the students reported to have access to computers at school, and nearly $90 \%$ at home. In addition, the great majority $(77 \%)$ of students had Internet access at home, and only in Iceland, Korea and Sweden did the number exceed $90 \%$. On average $85 \%$ of the students in OECD countries had a computer 
at home but less that $70 \%$ had an access to the Internet. Despite the possibilities, and the fact that the majority of 15-year old Finnish pupils had more than five years experience in using computers, Finnish youngsters' activity in using computers at home (78\%) exceeds only slightly the OECD average (75\%). The regular use of computers at school (36\%) was a little bit below the OECD average (43\%) and the number of computers per student somewhat above the OECD average. Moreover, according to the report, the attitudes towards the use of computers in Finland were not so positive as for example in Austria, Canada, Germany, Iceland and Portugal (see also Atjonen's and Li's introductory article).

These results are a little bit surprising because Finland has been seen as one of the leading countries in the use of Information and Communication Technology (ICT). Since 1995, Finland has also had national strategies in the use of ICT especially in education and research, and these strategies have been designed and administered by the Ministry of Education. One main goal of these strategies is to give students, at all levels of education, the basic skills for the information society and to educate teachers to become experts in the use of ICT in education in order to apply their expertise in their work. This means, in practice, that Finnish teacher education has a major responsibility for giving student teachers a realistic overview and knowledge of the possibilities and limitations of the use of ICT in education. Since the use of ICT in education is an area of constant change and development, teacher education can only offer future teachers starting point, basic principles and skills, and some conception of its use.

\subsection{ICT in Teacher Education}

From the point of view of student teacher education, it is important to define how ICT could be used to enhance learning and as a tool in the development of the information society (Niemi, 2003). Learning 'about, 'from' and 'with ICT' is discussed in literature. Learning 'about ICT' refers to ICT skills, not how ICT can support learning. Learning 'from ICT' refers mainly to a behaviourist view of learning, while learning 'with ICT' refers to a constructive view of learning. Learning with ICT moves the orientation from passive learning to active knowledge building (e.g., Jonassen, 1999). Learning 'with ICT' stresses the importance of human interactions, although traditionally interaction also includes interaction between learner and course content (Moore and Kearsley, 1996).

Learning from ICT or from the Internet cannot be forgotten in terms of gathering information and search engines are the most widely used applications among students and teachers. The Internet also serves as an important source of information for teachers. In initial teacher education, dimensions such as learning 'about', 'from' and 'with ICT' are insufficient. Therefore, it is more relevant to discuss how to activate learners, how to introduce various technologies (Ertmer, 2005) and how to find pedagogically relevant ways of using ICT in education. In this challenging process more attention should be paid to the learning experiences of student teachers and to their knowledge about the effective and meaningful use of ICT which, we assume, will to affect their willingness and motivation to use IT in education.

Every year, about 250 student teachers of education from the University of Joensuu, Finland take an introductory course in the use of ICT in education called "Information 
Technology and Learning". The content of the course focuses on connecting learning theories and ICT applications in practice, and it is compulsory for all student teachers. The course consists of lectures, a book exam and practical exercises, for example designing digital learning material. In the autumn of 2002 the book exam was replaced by a webbased learning environment. The purpose of the online environment was to guide student teachers in the use of modern ICT applications during their learning processes, to offer examples as to how ICT can be used in education, and to give the students an overview of the possibilities and limitations of ICT.

The aim of this paper is to investigate student teachers' ICT skills, their attitudes towards the use of ICT in education and dimensions of an online environment that may have a positive effect on students' attitudes toward the use of ICT in their work in the future. The changes in attitudes to the use of ICT in education during a web-course were also examined.

\section{Design and Implementation of the Learning Environment}

Designing a web-based course is a challenging process. This process involves connections of the teacher's knowledge, pedagogical solutions, and the possibilities and limitations of the technical environment. The environment has to be technically workable, supporting students' learning processes and preparing them for real life situations. According to Song et al. (2004), course design, leaner motivation, time management and comfort with online technologies, affect the success of an online learning experience. Therefore, effective instructional design includes technological and pedagogical aspects. The learners' goals, objectives and expectations should be facilitated by the online learning environment. Flexibility in study time assists students' strategies for managing their learning processes. Technical problems can frustrate learners, therefore it is important that a web-based environment is as user-friendly as possible. In measuring the quality of online learning, McGorry (2003) brings together pedagogical, usability, and technical aspects. The learner, the knowledge, the assessment of learning and the community are seen as key factors in planning learning environments (Bransford et al., 2005). Interaction between students and teacher is an important aspect in students' sense of community (Bransford et al., 1999). Interaction also refers to "communication" between the student and the learning material, especially when ICT replaces the teacher.

In addition to technical and pedagogical aspects, contextual possibilities and limitations (e.g., economical) have to be considered in order to make the design process realistic. In this study, the web-based course environment was constructed by adapting the evolutionary software development model (Kennedy, 1998; Pressman, 2000). In practice, this means that after analysing contextual possibilities and limitations, design and implementation of the pedagogical and technical solutions of the environment were iteratively carried out. 


\subsection{Guidelines for Designing the Environment}

The aim of the web-based course under study was to support students' self-directed learning processes in studying abstract concepts of learning theories and modern learning environments, and at the same time to practise students' ICT skills. On the other hand, the course was meant to automate teachers' administrative work (enrolment, feedback and exam grading, for example). Teachers' time was limited because they had as much/little time to handle the course as was the case when the formal book exam was carried out. This was the most important reason why interaction during this course was based only on the interaction between the student and the online learning environment, not between students and teachers, as is usually recommended (Bransford et al., 1999; McGorry, 2003).

The WebCT environment was chosen as a technical platform. This is widely used at the University of Joensuu, and at least some of the students were already familiar with it. This was seen as a strategy for diminishing technical problems, which is an important starting point in the design process (Song et al., 2004). There were also tools in the WebCT environment that automate certain tasks and so lessen the teachers' manual work. During the design process it was challenging to find solutions that support students' individual learning processes and help the administrative work of the course in this particular learning environment (e.g., Goldberg, 1997; Pain and Heron, 2003).

\subsection{Pedagogical Design of a Learning Environment}

One pedagogical aim of the web course was to offer scaffolding for individual selfschedulded studying that supports students' self-directed learning of new concepts and content. Preparing for a book exam in a new field of science (ICT in education) is a challenging task for students. There are many different ways of implementing theoretical concepts in practical solutions, when designing learning environments. The course design assumed that scaffolding of the studying process could be organised by offering enriched contextual support in the online environment (e.g., links to practical examples), the use of practising exercises for preparing for the assessment (conceptions of the most important issues and goals of studying) and experiences of studying in an online environment.

Research on learning from texts has focused quite a lot both on the features and structure of texts (e.g., McNamara et al., 1996) or additional elements such as graphics (Schnotz, 2002). In this case, books the students were expected to study were published as text books, and therefore it was impossible to make modifications to the texts. Theoretical discussion on learning from texts quite often refers to Kintch's construction-integration model of text comprehension. This emphasises an active processing of the text in order to build a mental model of the textual content. Kintsch (1986) makes distinction between the process of reading the text itself (mental model) and the process of integrating the textual content into the readers own knowledge system (situation model). The nature of the material, coherence or causality, can have a positive impact on the comprehension and learning of the text itself (Linderholm et al., 2000; McNamara et al., 1996) but it may not motivate deeper processing of the domain knowledge (Voss and Silfies, 1996). The text 
books in our environment were quite demanding, not only due to abstract concepts, but also to the foreign language and structure of the books (collection of articles). Therefore, the books are not so consistent in structure which may in some situations lead to active processing of the content (McNamara et al., 1996).

In order to support students' scaffolding we developed series of practising exercises in the form of multiple choice questions and essays. Traditional multiple-choice questions often test memory, not understanding or the application of knowledge. However, it is possible to make multiple-choice questions that require understanding (Bransford et al., 1999). Such questions do not demand definitions or facts, but rather the meaning of the facts, their reasons and consequences or setting theory into context (questions how, why and what for, instead of what is). The questions in the web course were meant to lead students to think, to understand what they read and to apply their knowledge to new situations. Ideally, when realizing the demands of the tests in the web course, they will study useful knowledge and meaningful content instead of just concentrating on trivial facts (Hudspeth, 1997). We also believed that the experience of studying the use of ICT in a web-based online environment itself, supports students' use of online environments in the teaching and learning process.

\subsection{Technical Design of a Learning Environment}

Students' personal learning processes were supported by the structure of the learning environment as follows (Fig. 1).

Since this course was a distance learning course, there was no possibility of giving technical training to students upon how to use the environment. Therefore students had

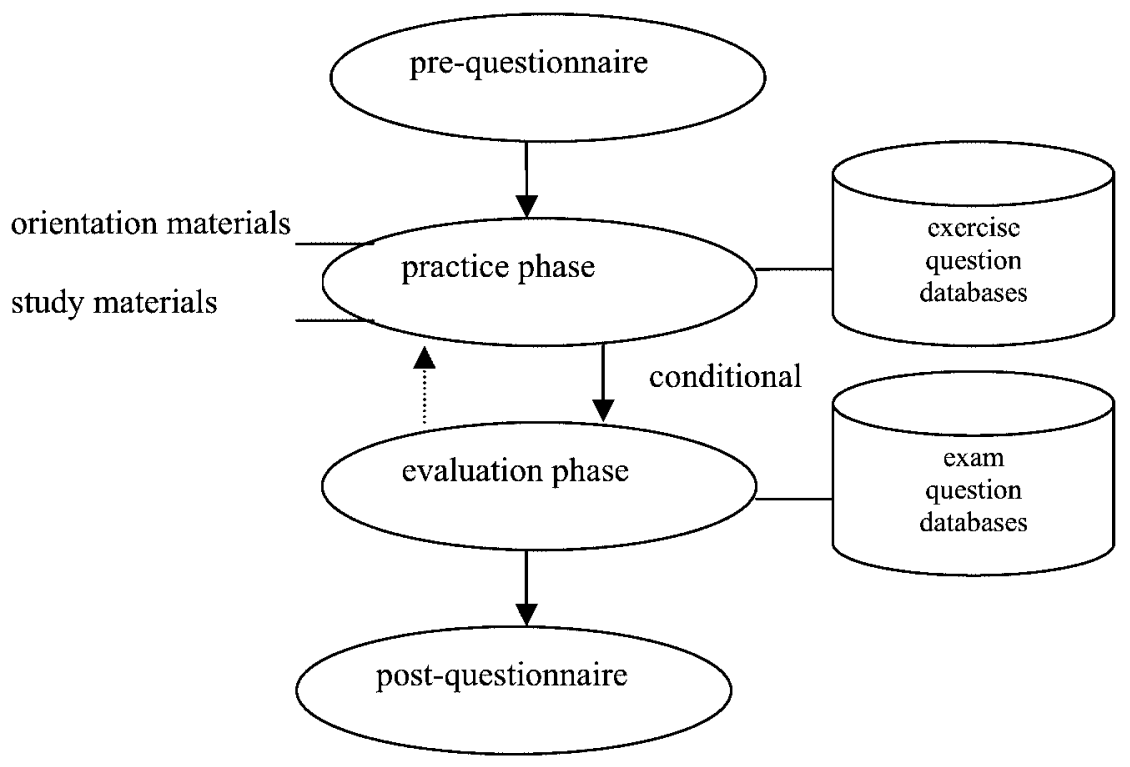

Fig. 1. Technical structure of the learning environment. 
to take a pre-questionnaire before the practice phase, and hence practise how the environment and tests work. The pre-questionnaire included structured (multiple choice) and open-ended questions. The pre-questionnaire was used for research purposes and did not include questions concerning course content. There was also a post-questionnaire in the environment, which was designed to measure students' attitudes, not the course content.

In the practice phase (see Fig. 1) students could use orientation materials, study materials and exercises. Orientation materials, including course description, guided students in setting their learning goals and instruction materials to evaluate their prior knowledge. These materials were partly designed to support students' understanding of the objectives of the course which is seen to be important for online learning (Song et al., 2004). These orientation materials were implemented as web pages, and students were given the opportunity to use these materials freely during their study period. Materials for increasing students' awareness of course issues, included study materials, which consisted of information on literature required. Some of these course books were also available on the Internet, and students were encouraged to use these online books. The environment also included extra materials (classified links to web resources) concerning the course content.

Students could practise their understanding and knowledge by doing exercises, which consisted of multiple-choice tests and open-ended questions. The environment included different tests according to credits and content. Students could chooce to take either a one or two credits test, and they were also able to choose which book(s) they wanted to study. Questions concerning each book were saved in separate databases. When students took the test, questions were taken at random from the databases. The students had to answer fewer questions than those in the databases. This technique meant that the chance for a student to have the same questions twice was small. Students could take these tests as many times as they liked. However, they had to have at least $70 \%$ of the answers correct before they could continue and take the exam. In the practice phase, students also had an optional possibility to practice essays. Practicing essays did not however affect the practice results.

Having practised the content of the course, students could continue to the evaluation phase (see Fig. 1). This consisted of exams. Exams were opened automatically for students who had passed the test in the practice phase. Exams were organized and implemented like exercises. So there were question databases and the questions were randomised online. Exams included multiple-choice questions and essays. The teacher was notified by an e-mail message when the exam was ready for grading. Students had two chances to take the exam. If s/he or he did not pass, access to the exam was automatically closed, and the student had to go back to the practice phase.

\subsection{Evaluation and Modification of the Learning Environment}

Students have evaluated the environment many times. Ten students tested the environment before its actual use, and for example one research was carried out during the first webcourse of 2002 (Rautopuro et al., 2003). The students evaluated the environment from the viewpoint of content and technique. 
Web-based learning is always restricted by the properties of the selected technical environment. In this case the course was meant to be in Finnish, but only an English version of the WebCT was available. This caused some problems that could not be solved. On the other hand, some problems were solved that were found during testing. Among these, the automatic WebCT feedback for the multiple choice test was considered to be ambiguous. In addition, some instructions on the practical exercises, exams, and the evaluation of the whole course were inadequate. All instructions and information were clarified and more information added. Of course, after each study missing links on the websites have been corrected, and the environment has been amended according to students' feedback.

\section{Methods and Data Collection}

Student teachers' ICT readiness have been studied several times at the University of Joensuu from 2001-2004 concerning their skills and attitudes towards the use of ICT in education and their opinions about dimensions of good learning environments (Rautopuro et al., 2003; Pöntinen and Rautopuro, 2004). These studies have also been used as tools for improving the course environment. This article deals with the study carried out in the autumn of 2003 and spring of 2004. All students entering the web-course answered a pre-questionnaire dealing with their ICT experiences and skills, and their attitudes towards the use of ICT in education. At the end of the course (after the web exam) the students answered a post-questionnaire in which the attitudes were re-measured. The post-questionnaire also consisted of an evaluation of the course environment. The students' attitudes (and the environment evaluation) were mainly measured with structured (Likert scale) questions supplemented with some open-ended questions.

Altogether 255 students answered the pre- and post-questionnaire and this group was very representative of the student teachers at Joensuu University. The majority of the students $(78.4 \%)$ were women. The mean age of the students was 26.3 years (median 24 years and standard deviation 6.9 years). The youngest students were 20 years old and the eldest was 48 years old.

Most of the students (41.1\%) were studying at the Faculty of Education. These students usually qualify for teaching posts in primary schools. $37.3 \%$ were students from the Faculty of Humanities and $21.6 \%$ from the Faculty of Science. These students will eventually qualify for teaching in secondary schools and upper secondary schools. Roughly a fifth (19.2\%) of the students were in the first stage of their studies (first or second year students), a little bit less than a half (43.1\%) were in the middle or in the last stage of their studies (third, fourth or fifth year students) and $37.7 \%$ had studied five years or more.

The data was mainly analyzed by using various statistical analyses. The students' ICT skills were mostly looked at in terms of descriptive statistics: frequencies, percentages, arithmetic mean, median and standard deviation. Relationships between qualitative variables were examined by using a chi-square test. The dimensions (scales) of students' evaluation were constructed with the help of factor analysis using oblim rotation (Afifi and Clark, 1996), and the reliability of the scales was measured by using the Cronbach's 
alpha coefficient. The Pearson correlation coefficient was applied to measure the linear association between the scales. The change in students' attitudes during the course was analysed using Wilcoxon's matched pairs test (Siegel and Castellan, 1988).

\section{Results}

\subsection{Teacher Students' ICT-Skills}

In the pre-questionnaire, the students were asked to describe how they use computers and also to evaluate their ICT-skills. A great majority of the students $(92.5 \%)$ had a computer at home and quite usually students $(58.8 \%)$ had Internet access at home too. All the respondents used word processing and email too some extent or even a lot. All the students used the Internet to seek information for their studies and almost all $(97.6 \%)$ used it also for their free time interests. About half (48.6\%) of the students totally agreed or somewhat agreed with the statement 'I use computers quite well' (less than $1 \%$ totally disagreed). On the other hand, the advanced use of computers was not so common. More than a half of the students $(54.5 \%)$ said they had never used spreadsheets. Graphics processing was as unfamiliar to the students as spreadsheets; $56.9 \%$ of the students had never used image-processing software. Furthermore, only $12.5 \%$ of the respondents had made WWW pages themselves.

There were some statistically significant differences in the use of ICT between male and female students. Female students used ICT for text processing $(p=0.000)$ more than male. The male students, on the other hand, used ICT more for emails ( $p=0.049$ ), Internet in free time $(p=0.031)$, graphics processing $(p=0.021)$ and www page editing $(p=0.019)$.

\subsection{Students' Opinions about the Use of ICT in Education}

Students' opinions about the use of ICT in education were measured by using 5-point Likert-scale statements ranging from 1 (totally disagree) to 5 (totally agree). Statements were based on general opinions about using ICT in education (e.g., Cox et al., 1999). The students' attitudes and changes in them during the course are shown in Table 1.

As we can see from Table 1, contrary to the result given in the OECD 2006 study among 15-year old youngsters in Finland (see chapter 1), student teachers' attitudes towards the use of ICT in education were very positive in the beginning of the course. When examining the proportions of "Totally agree" and "Somewhat agree" answers to statements in Table 1 it is easy to notice that attitudes became even more positive during the course. In total, $35.7 \%$ of the respondents reported that their attitude became more positive and only $2.7 \%$ had a negative change in their attitude. Furthermore, in most of the statements the positive change towards the use of ICT in education was statistically significant $(p<0.05)$.

It also seems that the web-based course gave the students some realistic ways of thinking. For example, the opinions that "computers cannot overtake traditional teaching" and 
Table 1

Students' opinions about the use of ICT in education

\begin{tabular}{|c|c|c|c|c|c|}
\hline \multirow{2}{*}{ Statements } & \multirow{2}{*}{$\begin{array}{l}\text { Proportion of students } \\
\text { who "totally agree" and } \\
\text { "somewhat agree" } \\
\text { in the beginning } \\
\text { (and at the end) of course }\end{array}$} & \multicolumn{3}{|c|}{ Opinion (number of students) } & \multirow{2}{*}{$p$-value } \\
\hline & & Strengthened & Weakened & No changes & \\
\hline $\begin{array}{l}\text { Computers are good } \\
\text { devices for learning }\end{array}$ & $84.2 \%(91.3 \%)$ & 82 & 24 & 147 & .000 \\
\hline $\begin{array}{l}\text { Computers increase } \\
\text { students' motivation }\end{array}$ & $60.4 \%(66.7 \%)$ & 74 & 52 & 129 & .111 \\
\hline $\begin{array}{l}\text { I believe I will use } \\
\text { computers in my } \\
\text { teaching }\end{array}$ & $81.6 \%(89.1 \%)$ & 80 & 18 & 157 & .000 \\
\hline $\begin{array}{l}\text { Computers cannot take } \\
\text { over traditional teaching }\end{array}$ & $82.4 \%(83.9 \%)$ & 62 & 37 & 156 & .028 \\
\hline $\begin{array}{l}\text { Computer based exam is } \\
\text { more agreeable than } \\
\text { 'traditional' paper and } \\
\text { pencil exam }\end{array}$ & $36.5 \%(51.9 \%)$ & 99 & 34 & 121 & .000 \\
\hline $\begin{array}{l}\text { The use of computers } \\
\text { makes studying more } \\
\text { interesting }\end{array}$ & $56.1 \%(60.8 \%)$ & 64 & 35 & 156 & .008 \\
\hline $\begin{array}{l}\text { Computers are not } \\
\text { suitable for every subject }\end{array}$ & $55.7 \%(52.5 \%)$ & 63 & 267 & 125 & .909 \\
\hline $\begin{array}{l}\text { Computers can be used as } \\
\text { a device for learning } \\
\text { routines }\end{array}$ & $79.6 \%(81.2 \%)$ & 64 & 51 & 140 & .175 \\
\hline $\begin{array}{l}\text { Computers should be } \\
\text { used only to support } \\
\text { traditional teaching }\end{array}$ & $39.6 \%(44.7 \%)$ & 76 & 49 & 150 & .036 \\
\hline $\begin{array}{l}\text { Computers weaken } \\
\text { students' routine skills }\end{array}$ & $31.1 \%(24.8 \%)$ & 43 & 68 & 130 & .010 \\
\hline $\begin{array}{l}\text { Computers weaken } \\
\text { students' collaboration } \\
\text { skills }\end{array}$ & $30.7 \%(23.9 \%)$ & 46 & 74 & 134 & .013 \\
\hline $\begin{array}{l}\text { Computers confuse } \\
\text { studying }\end{array}$ & $7.5 \%(5.9 \%)$ & 54 & 45 & 155 & .454 \\
\hline $\begin{array}{l}\text { Computers save students' } \\
\text { time in studying }\end{array}$ & $56.9 \%(52.2 \%)$ & 61 & 78 & 116 & .131 \\
\hline
\end{tabular}

"computers should be used only to support traditional teaching" strengthened during the course. These results also indicate that working in a web-based environment removes the doubts about ICT. In practice this means that after the web course the students were not so worried anymore that ICT ruins students' routine skills and collaboration. 


\subsection{Evaluation of the Environment}

Students' evaluation of the environment took place at the end of the course (after the exam) using 5-point Likert-scale statements ranging from 1 (totally disagree) to 5 (totally agree). The statements and the proportion of "totally agree" and "somewhat agree" can be seen in Table 2 .

The students' evaluations of the environment are quite positive, mostly when the statements deal with the content of the course. Of course, according to feedback from the students there are still details that need to be improved.

With the help of factor analysis the information gained fore the evaluations was reduced to dimensions (scales) of a good learning environment. The scales and their reliability coefficients are presented in Table 3.

The first dimension or the learning environment "Motivation and accuracy" refers to learning transfer, which requires that students are able to apply their knowledge and

Table 2

Students' evaluations of the course environment

\begin{tabular}{|c|c|c|c|}
\hline Statements & $\begin{array}{c}\text { Proportion of students } \\
\text { who "totally agree" } \\
\text { and } \\
\text { "somewhat agree" }\end{array}$ & Statements & $\begin{array}{c}\text { Proportion of students } \\
\text { who "totally agree" } \\
\text { and } \\
\text { "somewhat agree" }\end{array}$ \\
\hline $\begin{array}{l}\text { The environment is in } \\
\text { harmony with the } \\
\text { objectives }\end{array}$ & $70.1 \%$ & $\begin{array}{l}\text { Student may control } \\
\text { her/his own study pace }\end{array}$ & $84.9 \%$ \\
\hline $\begin{array}{l}\text { Information and content } \\
\text { of the course are current }\end{array}$ & $86.3 \%$ & $\begin{array}{l}\text { Required study time is } \\
\text { adequate }\end{array}$ & $81.4 \%$ \\
\hline $\begin{array}{l}\text { Instructions of the } \\
\text { environment are clear }\end{array}$ & $76.0 \%$ & $\begin{array}{l}\text { Student may control study } \\
\text { sequence }\end{array}$ & $66.2 \%$ \\
\hline $\begin{array}{l}\text { Navigation in the } \\
\text { environment is } \\
\text { trouble-free }\end{array}$ & $66.3 \%$ & $\begin{array}{l}\text { Information is presented } \\
\text { in a logical way }\end{array}$ & $77.7 \%$ \\
\hline $\begin{array}{l}\text { Practice exercises in the } \\
\text { environment are relevant }\end{array}$ & $81.5 \%$ & $\begin{array}{l}\text { The environment acts on } \\
\text { instructions }\end{array}$ & $79.6 \%$ \\
\hline $\begin{array}{l}\text { Information in the } \\
\text { environment is correct }\end{array}$ & $51.0 \%$ & $\begin{array}{l}\text { Examples of the } \\
\text { environment are proper }\end{array}$ & $73.3 \%$ \\
\hline $\begin{array}{l}\text { Level of the environment } \\
\text { is proper for the target } \\
\text { group }\end{array}$ & $75.6 \%$ & $\begin{array}{l}\text { Instructions of the } \\
\text { environment are adequate }\end{array}$ & $77.6 \%$ \\
\hline Information is usable & $86.7 \%$ & $\begin{array}{l}\text { Practice exercises support } \\
\text { the exam }\end{array}$ & $85.1 \%$ \\
\hline The feedback is varying & $27.8 \%$ & $\begin{array}{l}\text { The aims of the course are } \\
\text { documented clearly }\end{array}$ & $59.6 \%$ \\
\hline $\begin{array}{l}\text { The environment awakes } \\
\text { students' interest on the } \\
\text { subject }\end{array}$ & $52.2 \%$ & $\begin{array}{l}\text { The environment prepares } \\
\text { for real life tasks }\end{array}$ & $39.6 \%$ \\
\hline
\end{tabular}


Table 3

Dimension of a good learning environment

\begin{tabular}{|c|c|c|}
\hline $\begin{array}{c}\text { Motivation } \\
\text { and accuracy }\end{array}$ & $\begin{array}{l}\text { Learner-interface } \\
\text { interaction }\end{array}$ & $\begin{array}{l}\text { Learner control } \\
\text { and self-directed learning }\end{array}$ \\
\hline $\begin{array}{l}\text { - The environment awakes } \\
\text { students' interest on the } \\
\text { subject. The environment } \\
\text { prepares for real life tasks. } \\
\text { - Level of the environment is } \\
\text { proper for the target group. } \\
\text { - Information is usable. } \\
\text { - Practical exercises in the } \\
\text { environment are relevant. } \\
\text { - Information and content of } \\
\text { the course is up-to-date. } \\
\text { - The environment is in } \\
\text { harmony with the objectives. } \\
\text { - Practical exercises support the } \\
\text { exam. }\end{array}$ & $\begin{array}{l}\text { - Instructions in the } \\
\text { environment are clear. } \\
\text { - Instructions in the } \\
\text { environment are adequate. } \\
\text { - Information is presented in a } \\
\text { logical way. } \\
\text { - Navigation in the environment } \\
\text { is trouble-free. } \\
\text { - The environment acts on } \\
\text { instructions. }\end{array}$ & $\begin{array}{l}\text { - Required study time is } \\
\text { adequate. } \\
\text { - Student may control her/his } \\
\text { own study pace. } \\
\text { - Examples in the environment } \\
\text { are proper. } \\
\text { - Information and content of } \\
\text { the course is up-to-date. } \\
\text { - The aims of the course are } \\
\text { documented clearly. } \\
\text { - Information in the } \\
\text { environment is usable. }\end{array}$ \\
\hline Alpha $=0.84$ & Alpha $=0.84$ & Alpha $=0.70$ \\
\hline
\end{tabular}

skills in multiple contexts. Motivation is an important part of the learning process and it should be systematically recognized during the design process (Park and Lee, 2004). This dimension was also found in open-ended questions in the post-questionnaire in which students described their learning strategies outside the online learning environment. For example, students said that their working experiences and the application of technology to practical problems, helped them to understand the course content as follows:

"I read the course book twice! In addition I worked as a substitute teacher in an upper secondary

school. So, in practice, I used the Internet with pupils".

The second dimension "Leaner - interface interaction" of the environment refers to consistency and the appropriate visual presentation of the environment and study materials. It is also related to the learners' ability to use the communication medium facilitating the online course (Hill et al., 2004). Acceptably few errors and error recovery are also essential features of a good environment. The environment is associated with guidance and support, meaning that the environment is easy to learn and remember. At the same time, students control the usage of the environment. These usability features are commonly used in evaluation of learning environments (Squires and Preece, 1999; Grigoriadou and Papanikolau, 2000) and also generally in software development (e.g., Nielsen, 1993; Shneiderman, 1998).

The third dimension of the environment in Table 3 "Leaner control and self-directed learning." includes self-directed learning, tailoring the interface and metacognition (Squares and Preece, 1999). It also includes features of intentional and active learning where students have a possibility to plan their own study schedule, proceed individually and take responsibility for their learning process. Pace control requires the learning 
Table 4

Descriptive statistics for the course environment dimensions

\begin{tabular}{cll}
\hline Motivation and accuracy & $\begin{array}{c}\text { Learner-interface } \\
\text { interaction }\end{array}$ & $\begin{array}{c}\text { Learner control and } \\
\text { self-directed learning }\end{array}$ \\
\hline Mean $=3.84$ & Mean $=3.94$ & Mean $=4.08$ \\
Median $=3.87$ & Median $=4.00$ & Median $=4.17$ \\
Std.dev. $=\mathbf{0 . 5 6}$ & Std.dev. $=\mathbf{0 . 7 2}$ & Std.dev. $=0.50$ \\
\hline
\end{tabular}

environment to be flexible. These dimensions are also found to be indicators of high quality online learning studied by McGorry (2003) and Song et al. (2004). Dimensions of learner control and self-directed learning were also interpreted in students' descriptions of their learning process. For example, they mentioned the utilization of additional WWW-materials and books during their study process, and so diversified study materials mentioned in the followings:

"I studied course literature and sought further information, e.g., about experts. I also printed a part of the English material in order to study it more deeply."

Because the scales were constructed with the help of factor analysis using oblim rotation, the dimensions naturally correlated with each other. All the correlations (ranging from 0.51 to 0.75 ) were not only statistically significant $(p=0.000)$ but they also had practical significance. For example, the coefficient of determination (the effect size) between the scales "Motivation and accuracy" and "Leaner control and self-directed learning” ( $r=0.75$ ) was 56\%. This means in practice, that a learning environment with learner control features is also an environment which students find motivating (and vice versa).

Descriptive statistics for the three dimensions described above (student evaluations, range from value $1=$ low satisfaction to $5=$ high satisfaction) are shown in Table 4 . On the basis of the table, it is quite easy to conclude that students liked the web environment that substituted the old traditional "pen and paper" exam based on literature.

The students' satisfaction with the course environment can also be seen in the course success. Before the web environment, the number of students who did not pass the course was high (Rautopuro et al., 2003). Now only three students $(3.1 \%)$ had to take the exam more than twice and go back to the practice phase of the course. Almost $90 \%$ of the students passed the exam at the first attempt.

\section{Conclusion}

A review of the previous literature has revealed a range of issues relating to the involvement of ICT in education. Several factors affect teachers' willingness to use ICT, and especially web-based learning environments, in their work. Being easy to use and having demostrated its value in education ICT has a positive influence on teachers interest in it. 
Therefore, it is important that ICT and its possibilities are well introduced in teacher education. It is also important that student teachers have positive learning experiences from the use of ICT.

According to our results, learning new, abstract concepts can be supported by a well designed web-based environment. In our study the students were encouraged to study course material with the help of online-practices. The WebCT environment was in a way difficult to use, but made it possible to construct an environment that supported students' progress during the course. It supported both the students' learning processes in studying and evaluating theoretical content and assisted teachers in assessing their achievements.

The students felt that the web-based learning environment supported the achievement of individual learning goals and gave them skills that can be utilized in their future work. "Motivation and accuracy", "learner control and self-directed learning" and "learnerinterface interaction" of the environment, support students' learning processes and that demonstrate it increases students' already positive attitudes towards ICT in education. Students' experiences of studying individually in the web-based learning environment, together with the real-world examples, gave them the realistic vision of the role of ICT in education.

\section{References}

Afifi, A.A., and V. Clark (1996). Computer-Aided Multivariate Methods. Chapman and Hall, New York.

Bransford, J., A. Brown and R. Cocking (1999). How People Learn. Brain, Mind, Experience, and School. National Academy Press, Washington.

Bransford, J., L. Darling-Hammond and P. LePage (2005). Introduction. In J. Bransford and L. Darling- Hammond (Eds.), Preparing Teachers for a Changing World: What Teachers Should Learn and Be Able to Do. Jossey-Bass, San Francisco, pp. 1-39.

Ertmer, P.A. (2005). Teacher pedagogical beliefs: the final frontier in our quest for technology integration? $E T R \& D, \mathbf{5 3}(4), 25-39$

Goldberg, M. (1997). Using a web-based course authoring tool to develop sophisticated web-based courses. In B.H. Khan (Ed.), Web-Based Instruction. Educational Technology Publication, New Jersey, Englewood Cliffs.

Grigoriadou, M., and K. Papanikolaou (2000). Learning environments on the web: the pedagogical role of the educational material. Themes in Education, 1(2), 146-161.

http://hermes.di.uoa.gr/lab/CVs/papers\%5-Cpapanikolaou\%5Cgp_03.pdf.

Cox, M., C. Preston and K. Cox (1999). What factors support of prevent teachers from using ICT in their classroom? Paper presented in British Educational Research Association Conference, Univeristy of Sussex at Brighton, September 2-5.

http: //www.leeds.ac.uk/educol/-documents/00001304.htm.

Jonassen, D. (1999). Designing constructivist learning environments. In C.M. Reigeluth (Ed.), InstructionalDesign Theories and Models. A New Paradigm of Instructional Theory, vol. II. Lawrence Erlbaum Associates, Inc., New Jersey, pp. 215-240.

Kintsch, W. (1986). Learning from text. Cognition and Instruction, 3(2), 87-108.

Kennedy, D. (1998). Software development teams in higher education: an educator's view. In R.M. Corderoy (Ed.), FlexibilITy: The Next Wave. ASCILITE 98. Proceedings of the 15th Annual Conference of the Australian Society for Computers in Learning in Tertiary Education. University of Wollongong, Australia, pp. 373-386. http://www.ascilite.org.au/conferences/wollongong98/asc98-pdf/kennedymcnaughtni-0149.pdf.

Linderholm, T., M.G. Everson, P. van den Broek, M. Mischinski, A. Crittenden and J. Samuels (2000). Effects of causal text revisions on more- and less-skilled readers' comprehension of easy and difficult texts. Cognition and Instruction, 18(4), 525-556. 
McGorry, S. (2003). Measuring quality in online programs. Internet and Higher Education, 6, 159-177.

Nielsen, J. (1993). Usability Engineering. Academic Press, Boston (Mass).

McNamara, D.S., E. Kintsch, N.B. Songer and W. Kintsch (1996). Are good texts always better? Interactions of text coherence, background knowledge, and levels of understanding in learning from text. Cognition and Instruction, 14(1), 1-43.

Niemi, H. (2003). Towards a learning society in Finland: Information and communications technology in teacher education. Technology, Pedagogy and Education, 12(1), 85-103.

OECD (2006). Are Students Ready for a Technology-Rich World? What PISA Studies Tell Us. http://www.oecd.org/document/31/0,2340,en_32252351_32236173_35995743 _1_1_1_1,00.html.

Pain, D., and J. Heron (2003). WebCt and Online Assessment: the best thing since SOAP? Eduacational Technology and Society, 6(2), 62-67.

Pressman, R. (2000). Software Engineering: A Practitioner's Approach. McGraw-Hill Publishing Company, Berkshire.

Pöntinen, S., and J. Rautopuro (2004). Supporting teacher students' use of information and communication technology in education. In Kinshuk, Demetrios, Pedro (Eds.), Cognition and Exploratory Learning in Digital Age (CEDLDA 2004), pp. 517-520.

Rautopuro,J., K. Leinonen, S. Pöntinen and J. Kukkonen (2003). Metamorphosis in teacher education: transforming a dreadful book exam in a constructive virtual learning environment. Paper presented in ISATT'03 Conference, Leiden, Netherlands.

Schnotz, W. (2002). Towards an integrated view of learning from text and visual displays. Educational Psychology Review, 14(1), 101-120.

Shneiderman, B. (1998). Designing the User Interface: Strategies for Effective Human-Computer Interaction. Addison-Wesley.

Siegel, S., and N.J. Castellan (1988). Nonparametric Statistics for the Behavioral Sciences. McGraw-Hill, New York.

Song, L., E. Singleton, J. Hill and M. Hwa Koh (2004). Improving Online Learning: Student perceptions of useful and challenging characteristics. Internet and Higher Education, 7, 59-70.

Squires D., and J. Preece (1999). Predicting quality in educational software: Evaluating for learning, usability and the synergy between them. Interacting with Computers, 11(5), 467-483.

Voss, J.F., and L.N. Silfies (1996). Learning from history text: The interaction of knowledge and comprehension skill with text structure. Cognition and Instruction, 14(1), 45-68. 
J. Rautopuro - senior assistant (computer assisted instruction) at Department of Applied Education, University of Joensuu. His current research interests are teaching and learning of quantitative research methods; virtual learning environments.

S. Pöntinen - lecturer (educational technology, pedagogy of information technology) at Department of Applied Education, Univeristy of Joensuu. Current research interest pre-service teacher education and educational technology.

J. Kukkonen - instructional designer at Department of Applied Education, University of Joensuu. Current work: organizer of open and distance education in teacher education; chairman of the expert unit in information and communication technology in education (TOTY) 


\section{Informacinès visuomenès link - Suomijos mokytojų švietimo atvejis Juhani RAUTOPURO, Susanna PÖNTINEN, Jari KUKKONEN}

Informaciniu ir komunikaciniu technologiju (IKT) naudojimas švietime yra svarbi kompetencija, kuri turi būti ugdoma mokant būsimus mokytojus. Tam, kad pajègtu IKT pritaikyti švietime, būsimi mokytojai turi studijuoti ir pedagoginius, ir techninius dalykus. Siekiant, kad būsimi mokytojai norètu ir būtụ pasiruošę naudoti IKT savo darbe, reikia skirti daugiau dèmesio jụ mokymosi patirčiai. Straipsnyje nagrinėjamas būsimų mokytojų požiūris ị IKT panaudojimą švietime prieš jiems pradedant lankyti žiniatinkliu paremtą kursą ir jị pabaigus. Remiantis studentų mokymosi patirtimi, požiūriais ir vertinimais, susijusiais su žiniatinkliu paremta mokymosi aplinka, nagrinėjamos sèkmingos žiniatinkliu paremtos mokymosi aplinkos dimensijos. Tyrimo rezultatai atskleidžia, jog būsimus mokytojus IKT savo darbe naudoti labiausiai skatintų tokios savybès kaip „motyvacija ir tikslumas“, „,besimokančiojo ir vartotojo sąsajos tarpusavio sąveika“ ir „besimokančiojo priežiūra ir ị save orientuojamas mokymasis“. Tinkamai sukurta mokymosi aplinka taip pat leidžia susidaryti realistišką požiūrị ir deramai suprasti IKT panaudojimo švietime galimybes ir ribas. 